\title{
RSF1 Gene
}

National Cancer Institute

\section{Source}

National Cancer Institute. RSF1 Gene. NCI Thesaurus. Code C49129.

This gene is involved in chromatin remodeling and regulation of gene transcription. 